\title{
READERS
nusight
}

\author{
Journal of Economic Info (JEI) \\ ISSN:2313-335X \\ www.readersinsight.net/jei
}

\section{Profitability of cement industry of Pakistan in different political scenarios}

\author{
Agha Amad Nabi ${ }^{1 *}$ \\ ${ }^{1}$ Faculty of business Administration IQRA University Pakistan \\ * Corresponding author: ammadagha786@gmail.com
}

\begin{abstract}
Monetary condition of any firm is the most important factor to judge its profitability. Present study aimed at studying the cement industry's profitability in democratic as well as autocratic governments in Pakistan. The results show the performance of cement industry of Pakistan in different political regimes by taking into account three variables (size, leverage and profitability). The impact of financial leverage on the firm's profitability has always been the most interesting one and according to (Titman \& Wassels, 1988) those organizations that utilize their income instead of taking outside capital procure more benefit as compare to the organizations which depend more on outside capital which increment their leverage.
\end{abstract}

\section{ARTICLE INFORMATION \\ Received: 15 November 2014 \\ Revised: 12 January 2015 \\ Accepted: 25 January 2015}

DOI 10.31580/jei.2i1.86

\section{Introduction}

The monetary condition of the organizations is the most crucial factor for exploration in the field of finance and the firms that got delisted from the Karachi stock exchange are referred to as insolvent (Alifiah, 2011).

Rajan and Zingales, (1995) have suggested that in order to identify the company profitability, financial leverage plays an important role. Most of the firms avoid taking debt because of paying higher amount of money to creditors as it leads to the lower profit for the firm or in other words lower profitability of a firm. High leverage offers advantages to the firms only when the economy is at the peak of its business cycle because of higher productivity, higher sales, higher employment and most importantly increase in demand for goods and services. However during the economic recession using the financial leverage can bring negative effect to the firm's profitability as the firms won't be able to meet the interest expense. This could happen on the grounds that the productivity of the firm will be low. (Zingales, 1995).

In Pakistan the first dictatorship rule take into place during the year (1958 -1971) when Ayub khan seized the power from Iskander mirza and replace the democratic rule into autocratic rule. The second autocratic rule took place in the year (1977-1988) when zia ul haq took the government in to his hands, whereas the last and the third one dictatorship rule took place in Pakistan in the year (1999-2008) in which General Pervez Musharraf seized the government of Pakistan. One of the extraordinary historic issues to the consistency of equality in underdeveloped countries that they are subordinating the armed to civilian government. The best prominent appearance of this fight has remained the occurrence of armed forces. However, with the third development of democratization and the finish of the cold war, scientists have guaranteed that we have arrived to a new period of military relationship in which positive armed forces besides democracies will be mutual. (Yaqub, 2010).
In year1999, the military forces took control over the democratic government as well as seized the power. In 2002 elections were held and military came into power and in the year 2002 remedial measures took place in the following era and different sectors of Pakistan started to make profits. In 2008 decisions were held and democratic rule comes to power again in Pakistan as a result same issue started to happen again due to high interest rate because of increase in the rate of inflation different sectors of Pakistan gets badly affected by it. According to the researcher (Ali and Afzal, 2012) the substantial part concerning the bankruptcy predictors are the determinants of leverage as well as the power of institutional differences across developed, emerging and developing countries (Ali and Afzal, 2012). Hence With these perspectives, this study examines the significant default prediction determinants of Pakistan's cement sector with respect to firm's size, profitability, leverage and different political periods.

Agha, (2017) stated that cement industry is one the most prosper industrial sector of Pakistan due to its increase in demand for residential and commercial projects. According to APCMA (All Pakistan Cement Manufacturing Association) the demand for cement increase by $10 \%$ in the fiscal year 2016. The political factor is influencing the progress of the cement industry of Pakistan because of the poor economic growth, lack of government interest, high tax rate due to which production cost increase and high real estate and housing crisis are the chief reason due to which the cement industry of Pakistan is not progressing. The purpose of this study is to analyze the profitability of cement industry in different political regime that is democratic and dictatorship period.

\section{Literature review}

In this research the firm level ratios are used. In order to measure the financial or monetary distress. Researchers (Suresh Ramakrishna, Agha Amad Nabi. etal. 2015) in order to measure the financial distress have used variables such as: profitability, size, leverage and liquidity. The independent variable that has been used in this research 
are It implies a portion of profit on a business' venture and it shows the strength of the organization. (Suresh Ramakrishna, Agha Amad Nabi, Etal. 2015). Large organizations have a more prominent capacity to borrow due to stable cash flow that reduces the chance of bankruptcy as compare to small business. (Suresh Ramakrishna, Agha Amad Nabi. Etal. 2015).Leverage ratio show the amount of investment in a business which is raised by secure interest borrowings. (Suresh Ramakrishna, Agha Amad Nabi, Etal. 2015).

Leverage ratio show the amount of investment in a business which is raised by secure interest borrowings. High level of borrowings by a business is measured to be highly geared while a business that depends on equity tend to have low geared.

Firm profitability can be portrayed by the cost of its stock. The stock price of those firms is higher who issue equity for capital as compared to those firms who use the leverage to get the capital (Mandelker \& Rhee, 1984). According to (Wald, 1999) debt to asset ratio has negative relation with the firm's profitability and performance and he did his review on the company's capital structure which works in United State, United Kingdom, Japan, France, and Germany. He considered firm size, development and association's peril as illustrative factors.

Mandelker \& Rhee (1984) clarified that the most profitable firm in numerous ventures or industries tend to have the least leverage proportion. It has been found that huge abnormal positive returns for an association's stockholders are related with leverage expanding occasions. Despite the fact that gross domestic product (GDP) has been relentlessly developing throughout the previous couple of years in Pakistan, its development at $8.4 \%$ amid 2004-05 has been exceptional. Pakistan is being evaluated as one of the five Asian economies demonstrating quickened pace of development. The growth in the demand of cement has accomplished the most in the year 2004-2005, almost 2.5 times of the development in GDP (Mangalam \& Govindasamy, 2010).

Financial leverage and operational leverage are the section of total leverage which influences the benefits of the organizations, stock price of the organization and market value of shares (Denis etal, 2012). Financial leverage is considered as cost saving and tend to have lower chances of risk for the owners but it will become costly if not efficiently utilized then organizations need to pay financial charges on the leverage. The companies will also suffer from other problems like: returning back the leverage amount with the interest expense.

Large organizations have a more prominent capacity to borrow due to stable cash flow that reduces the chance of bankruptcy as compare to small business. Cost of insolvency is truly important to determine the best anticipation because these costs represent the financial performance of the company for the investors.

The impact of organization size on profitability has been addressed by various researchers. These studies have been applied nationwide, most part have been utilized to measure the return on assets ratio or the net profit or both of them, total assets and total sales, and in some studies the number of employees as a measures for company size for a different time periods, different sample sizes, and a different company sectors.

Abiodun (2013) stated that the impact of the size of the organization on its profitability for the assembling and manufacturing organizations recorded in the Nigerian Stock Exchange conducted during the period 2000 to 2009 and he found a huge positive connection between size of the company and productivity.

On the other hand similar studies found weak relationship between organization size and profitability, or found no connection between organization size and productivity, or negative and unimportant relationship between organization size and profitability for one or more sector. A current report by (Niresh \& Velnampy, 2014) investigated the impacts of firm size on profitability for 15 producing organizations establish in Colombo Stock Exchange (CSE) for the period from 2008 to 2012 has discovered no connection between firm size and benefit, and size has no significant effect on profitability.

It implies a portion of profit on a business' venture and it shows the strength of the organization. High efficiency shows that organizations are profitable and vice versa. Subsequently, this examination demonstrates that there is a negative relationship among the profitability as implied by money distress.

Each firm is most concerned about its profitability. Profitability measures are important to organization managers and proprietor. The primary owner needs to show profitability to the equity investors who have put their own money into the company. Company's overall performance and efficiency is demonstrated by profitability ratios.

Padachi (2006) found that if the firm is invested higher in the inventories then the ideal level will reduce and profitability will go down. (Teruel \& Solano, 2007) clarified that organization's profitability would be increased by reducing the days in receivables, days in inventories and length of cash cycle. Hutchison et al. (2007) perceived the relationship of cash conversion cycle with the investment returns. Profitability increase the value of stakeholders and investors.

The dependent variable that is going to be use in this study is the political influence.

Democracy is always being welcomed in most parts of the world whereas dictatorship rule is more directed towards their own advantage (allocation of budgets) as compared to spending budget on civilians and non-defense projects (Ahmad et al., 2012).

The democratic system is more beneficial as contrast to dictatorship rule in terms of development, speculation, soundness and giving a shot to reelect. If the past government failed to achieve the expectations they can be expelled by its resident in next elections. Democratic system is about individuals' control. Dictatorship is seen as political instability That is dictatorship failed to generate economic growth and Negative consequences over health, education and investments were seen after overthrowing democracy regime.According to Ibrahim, when economy is shrinking it has more chances to be over taken by military dictators (Mittoo and Bancel, 2011; Zarebski and Dimovski, 2012).

During the 69 years of Pakistan's history, military (Dictatorship) control and Democratic governments have been imposedon Pakistan. Each has an alternate method for administration and subsequently different economic and social results. The nation has seen four military standards: Field Marshal Ayub Khan from 1958, Gen. Yahya Khan from 1969, and Gen. Zia-ul-Haq in 1988and Gen. Pervez Musharraf from 1999. Before the Musharraf's rule, every democratic government had been taken over by a military rule and as a result the democracy in Pakistan could not be able to remain on its feet till after 2007. In 2013, for the first time the democratic government of Pakistan completed its five constitutional years. When Gen. Pervez Musharraf took over the government from Nawaz Sharif in 1999, the size of Pakistan's economy was just $\$ 70$ billion. In the following 8 years the figure increase to $\$ 170$ billion and Pakistan was among the top of the developing economies of the world. The national treasury had just \$0.4 billion and Pakistan was on the edge of becoming insolvent but by the end of dictatorship, national treasury was credited with $\$ 18$ billion. Further the debt of Pakistan from $\$ 38.5$ billion to $\$ 34$ billion. Today after around 8 years of his departure foreign exchange stands at Rs.108.4 which when he left was Rs.60 and inherited at Rs.55. Pakistan remained fruitful in drawing in $\$ 5152.80$ million of foreign investment during President Pervez Musharraf era, which in succeeding regime declined to $\$ 1456.5$ million and additionally dwindled to $\$ 1281.1$ million during the first half of the present government (Fosberg, 2010).

PML-N the confidence of the foreign investors. As indicated by the World Bank and IFPRI report, poverty was cut half from $34.5 \%$ to $17.2 \%$ by targeted interventions and social safety plans during the dictatorship of Musharraf. In his successor regime, BISP was launched by the PPP government which was a great step towards eradicating poverty and later continue by the PML-N government.

Figure 1 shows the independent and dependent variables, the independent variables of this study are: profitability, size and leverage whereas the dependent variable of this research is political influence. 


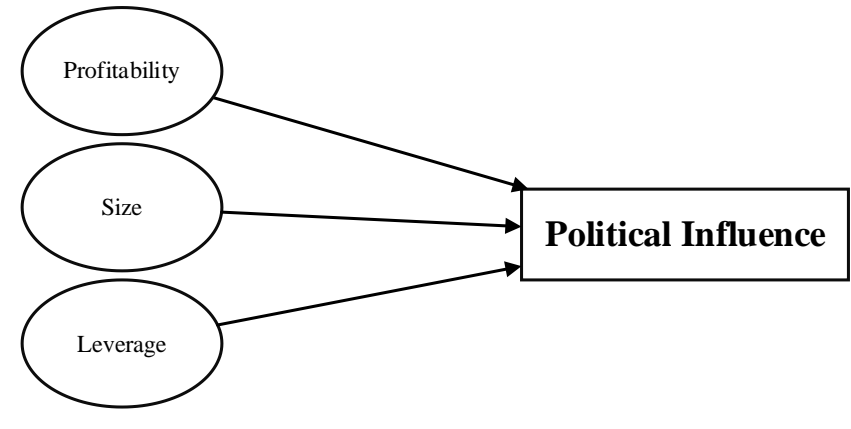

Fig. 1. Dependent variable

H1: There is significant difference between autocratic and democratic government for profitability of firm.

H2: There is significant difference between autocratic and democratic government for leverage of firm.

H3: There is significant difference between autocratic and democratic government for size of firm.

The relationship between the independent variables (leverage, profitability and size) and dependent variable (Political influence) has been discussed.

\section{Research methodology}

Research methodology is the method use to collect the data and information for the purpose of making the business decision. There are various methods to collect the data which include interviews, surveys, publications, books and newspaper. In order to conduct the research both historical and present data can be used.
In order to conduct the research the secondary data has been taken from the sources like: Karachi stock exchange (KSE), security exchange commission of Pakistan (SECP), federal bureau of statistics (FBS) and state bank of Pakistan (SBP).

Independent sample $t$ test is used to compare the mean of the two sample in order to conclude whether there is any statistical evidence that the population means of the two sample are considerably different or not.

$$
t=\frac{\left(x_{1}-x_{2}\right)}{\sqrt{\frac{\left(s_{1}\right)^{2}}{n_{1}}+\frac{\left(s_{2}\right)^{2}}{n_{2}}}}
$$

$\mathrm{n} 1=$ No of observations of sample 1 $\mathrm{n} 2=$ No of observation of sample 2

$\mathrm{x} 1=$ Mean of sample 1

$\mathrm{x} 2=$ Mean of sample 2

$\mathrm{x} 1-\mathrm{x} 2=$ Mean difference

$\mathrm{S} 1=$ Variance of sample 1

S2=Variance of sample 2

In this research have discussed about the research methodology, Independent $\mathrm{t}$ test and the data collection method.

\section{Results and discussion}

The Independent-Samples $\mathrm{T}$ Test is used to find the difference between the mean of two samples.

Table 1 depicts the sample size, mean standard deviation and standard error of the two samples of the study that is democratic and autocratic. In Table 4.1, the mean of the variable leverage is better in democratic because the mean of the leverage is less in democratic (0.595) as compare to autocratic (0.635). The mean of the variable size is better in democratic regime (6.486) as compare to autocratic (6.009). Whereas, the growth is better in autocratic regime because the mean of growth is greater in autocratic (0.927) than democratic (0.476).

Table 4.1: Sample size, mean standard deviation and standard error of the two samples

\begin{tabular}{llllll}
\hline & Govt & N & Mean & Std. Deviation & Std. Error Mean \\
\hline \multirow{4}{*}{ SD } & Democratic & 69 & .59533760077 & .264686930969 & .031864561985 \\
\multirow{3}{*}{ Growth } & Autocratic & 101 & .63495392103 & .386690670662 & .038477159842 \\
& Democratic & 71 & 6.4856147715 & 1.28726497123 & .15277024571 \\
& Autocratic & 101 & 6.0086157283 & 1.68754969953 & .16791747114 \\
& Democratic & 70 & .476454 & .7314261 & .0874221 \\
& Autocratic & 102 & .927407 & .7868276 & .0779075 \\
\hline
\end{tabular}

Table 2: Independent Samples Test

\begin{tabular}{|c|c|c|c|c|c|c|c|c|c|c|}
\hline & \multicolumn{2}{|c|}{$\begin{array}{l}\text { Levene's Test } \\
\text { for Equality of } \\
\text { Variances }\end{array}$} & \multicolumn{7}{|c|}{ t-test for Equality of Means } \\
\hline & & \multirow[b]{2}{*}{$\mathbf{F}$} & \multirow[b]{2}{*}{ Sig. } & \multirow[b]{2}{*}{$t$} & \multirow[b]{2}{*}{ df } & \multirow[b]{2}{*}{ Sig. (2-tailed) } & \multirow[b]{2}{*}{ Mean Difference } & \multirow[b]{2}{*}{$\begin{array}{l}\text { Std. Error } \\
\text { Difference }\end{array}$} & \multicolumn{2}{|c|}{$\begin{array}{l}95 \% \text { Confidence Interval of the } \\
\text { Difference }\end{array}$} \\
\hline & & & & & & & & & Lower & Upper \\
\hline \multirow[t]{2}{*}{ TD } & $\begin{array}{l}\text { Equal variances } \\
\text { assumed }\end{array}$ & .040 & .841 & -.740 & 168 & .460 & -.039616320262 & .053506298512 & -145247662416 & .066015021893 \\
\hline & $\begin{array}{l}\text { Equal variances } \\
\text { not assumed }\end{array}$ & & & -.793 & 167.997 & .429 & -.039616320262 & .049958404098 & -.138243474344 & .059010833821 \\
\hline \multirow[t]{2}{*}{ Size } & $\begin{array}{l}\text { Equal variances } \\
\text { assumed }\end{array}$ & .818 & .367 & 2.006 & 170 & .046 & 47699904321 & .23779391761 & .00758987687 & .94640820955 \\
\hline & $\begin{array}{l}\text { Equal variances } \\
\text { not assumed }\end{array}$ & & & 2.101 & 168.822 & .037 & 47699904321 & 22701327073 & .02884864086 & .92514944556 \\
\hline \multirow[t]{2}{*}{ Growth } & $\begin{array}{l}\text { Equal variances } \\
\text { assumed }\end{array}$ & 4.359 & .038 & -3.799 & 170 & .000 & -.4509530 & .1187073 & -.6852831 & -.2166229 \\
\hline & $\begin{array}{l}\text { Equal variances } \\
\text { not assumed }\end{array}$ & & & -3.851 & 155.230 & .000 & -.4509530 & .1170992 & -.6822665 & -.2196395 \\
\hline
\end{tabular}

Table 2, Levene's Test for Equality of Variances depicts the two test that shows the difference between the two samples. The levene's test assumed that the variance of the two sample are equal or same. The test shows that the significance value is greater than 0.05 of this research which means that the variance of the two sample are equal. Table 4.2, t-test for Equality of Means shows that leverage is better in autocratic regime as compare to democratic regime because the value of mean difference is negative and is insignificant. It also shows that the cement firms are performing better in terms of size in democratic era because the value of mean difference is positive and is significant. Whereas the profitability of the firms is better in autocratic era because the value of mean difference is negative and is significant.

The $t$ in the table shows the no of observations for each sample. The $\mathrm{df}$ (degree of freedom) in the table is used to equal the no of cases in both the sample or group. The mean difference shows the difference 
between the mean of the two sample. The $95 \%$ confidence interval shows the boundaries in which the mean of the two sample would lie. The results shows that the cement industry of Pakistan can gain higher profit in autocratic regime as compare to democratic regime that is the mean value of profitability in autocratic 0.9274 is greater than democratic 0.4764 . Whereas the size of the cement industry is expanding in democratic era instead of autocratic era that is the mean value of size in autocratic 6.009 is less than democratic 6.486 . The study further shows that the leverage of the cement industry of Pakistan is better in democratic regime because the mean value of leverage in autocratic 0.6349 is greater as compare to democratic 0.5953 .

This refers to the factor or characteristics that the researcher cannot control or that can affect the study or research. This study was conducted to determine the profitability of cement industry of Pakistan in different political regimes. In this study only three variables has been used that are size, profitability and leverage other variables (liquidity or current ratio) can be explored by the future researcher as well as the contribution of the cement sector in the Gross domestic product of Pakistan.

\section{Conclusion}

Cement industry is one of the few businesses that existed in Pakistan before the partition of the sub-continent. The real purpose behind the presence of this industry is the accessibility of the raw materials as well as the increase in the demand of cement in Pakistan.

Regardless of having a well-developed industry, Pakistan's per capita cement utilization which remains at $140 \mathrm{kgs}$, is the least as compared to other countries - the worldwide normal is $400 \mathrm{kgs}$ for each capita.
Poor financial development, absence of government enthusiasm for foundation tasks and high land and lodging costs have kept the local demand of cement low and for a long time, cement manufacturers particularly those situated in the south locale (Sindh and Balochistan), have focused mainly on exports. Cement manufacturers in the north (KPK and Punjab) have shied far from exports because of restrictively high expenses of inland transportation.

The results of the study indicate that the cement industry of Pakistan is highly reactive and associated with political and economic conditions of Pakistan. The study shows that the impact of financial and monetary distress is different in each political regimes that is the size, leverage and profitability are different in democratic regime as compared to autocratic era.

\section{References}

Ramakrishnan, S., Nabi, A. A., \& Anuar, M. A. (2016). Default Prediction in Pakistan using Financial Ratios and Sector Level Variables. International journal of economics and Financial Issues, 6(3S).

Ramakrishnan, S., Nabi, A. A., Daud, Z., \& Anuar, M. A. (2016). Impact of Sector Level Variables on Political Scenarios in Pakistan. International Journal of Economics and Financial Issues, 6(3S).

Nawaz, A., Salman, A., \& Shamsi, A. F. (2015). Impact of financial leverage on firms' profitability: An investigation from cement sector of Pakistan.

Zubairi, H. J. (2010). An investigation of the influence of key financial and economic indicators on profitability of cement sector companies in Pakistan.

Ali, N., Anwer, M., Jaffar, A., \& Raza, M. (2015). The cement industry of Pakistan: A swot analysis.

Nawaz, A., Salman, A., \& Shamsi, A. F. (2015). Impact of financial leverage on firms' profitability: An investigation from cement sector of Pakistan. 